\title{
DESCRIPTIONS OF TWO NEW SPECIES OF SQUALOID SHARKS FROM JAPAN.
}

\author{
By David Starr Jordan ${ }^{1}$ and John Otterbein Snyder, \\ Of the Leland Stanford Junior University.
}

In the present paper is given a description of two new species of sharks from the deeper waters of the east coast of Hondo, the main island of Japan. Both species belong to the family of Squalidæ.

I. ETMOPTERUS LUCIFER Jordan and Snyder, new species.

Head about $4 \frac{3}{4}$ in length; depth about 7 ; snout about $2 \frac{3}{4}$ in head; eye $5 \frac{3}{5}$ in head; 2 in snout, $2 \frac{4}{11}$ in the width of snout, and $2 \frac{9}{11}$ in the space from the tip of the snout to mouth; space between spiracles $2 \frac{1}{2}$ in the width of snout.

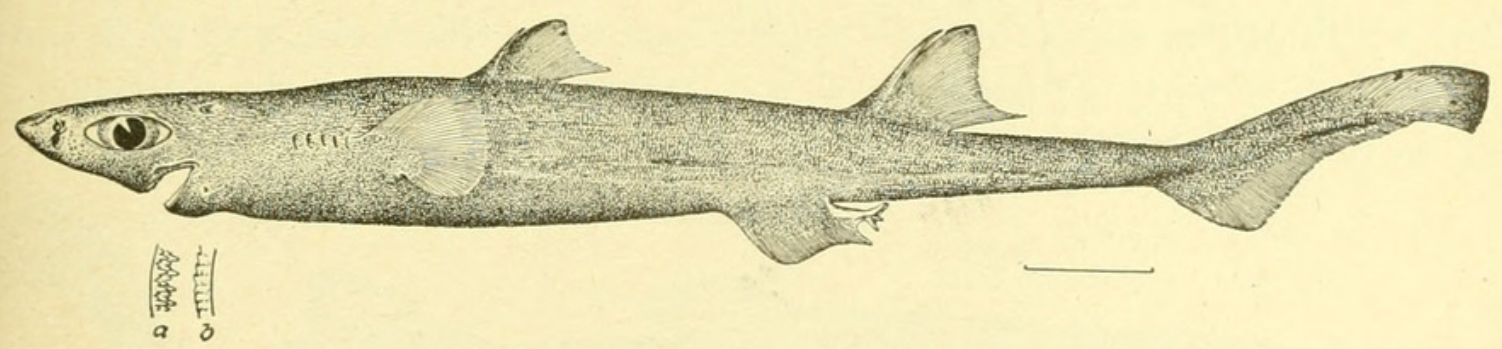

Fig. 1.-Etmopterus Lucifer. $a$, upper jaw; $b$, lower jaw.

Body moderately elongate, rather robust, and with slender caudal peduncle; scales rough, small, forming longitudinal striæ above, abruptly and sharply separated on the sides from the lower surface, which is evenly rough with fine shagreen.

Head large, thick, rather short; snout rather short, thick, more convex below than above, and also with many pores; eyes moderate, lateral, and with anterior margin midway between the tip of the snout and the spiracle; skin about the eyes more or less loose and free, and the upper eyelid overlapping and forming a pit in front; nostrils very large and lateral; mouth opening below the posterior portion of the

\footnotetext{
${ }^{1}$ Assisted by Henry W. Fowler.
} 
eye and broad; lips rather thin; teeth small, compressed, and each of those in the upper jaw with two sharp basal cups; spiracles large, nearer the eye than the first gill opening, and the space between $1 \frac{1}{7}$ in the snout. Gill-opening in front of the base of the pectoral, and rather short. Dorsal fins each with a spine, the base of the first a little before the tip of the pectoral, short, sharp pointed and projecting a little above the skin; the second dorsal spine not as high as the fin, but much larger and longer than the first, with the greater portion exposed, and nearly a third greater than the snout; ventrals moderate and entirely in front of the second dorsal; caudal elongate and the lower lobe little produced.

Color in spirits dark grayish brown, and the lower margin of the caudal, together with the marginal portions of all the other fins, very pale brown. The pale areas on the sides of the belly cover a glandular substance said to be luminous in life.

This description from specimens from Misaki, measuring 12 inches, from the collection of Capt. Alan Owston, No. 6863, Stanford University Zoological Museum. Some thirty others of the same species were obtained off Misaki on long lines handled by Mr. Kumakichi Aoki, assistant to Professor Mitsukuri.

LEANIA, new genus.

2. DEANIA EGLANTINA Jordan and Snyder, new species.

Head $3 \frac{3}{4}$ in length; depth about $9 \frac{2}{3}$; snout about 2 in the head, 2 in the width of the snout; eye $4 \frac{6}{7}$ in the head, $2 \frac{6}{7}$ in the snout, and $3 \frac{5}{7}$ in the space between tip of snout and mouth; space between the spiracles, $1 \frac{2}{3}$ in the width of the snout.

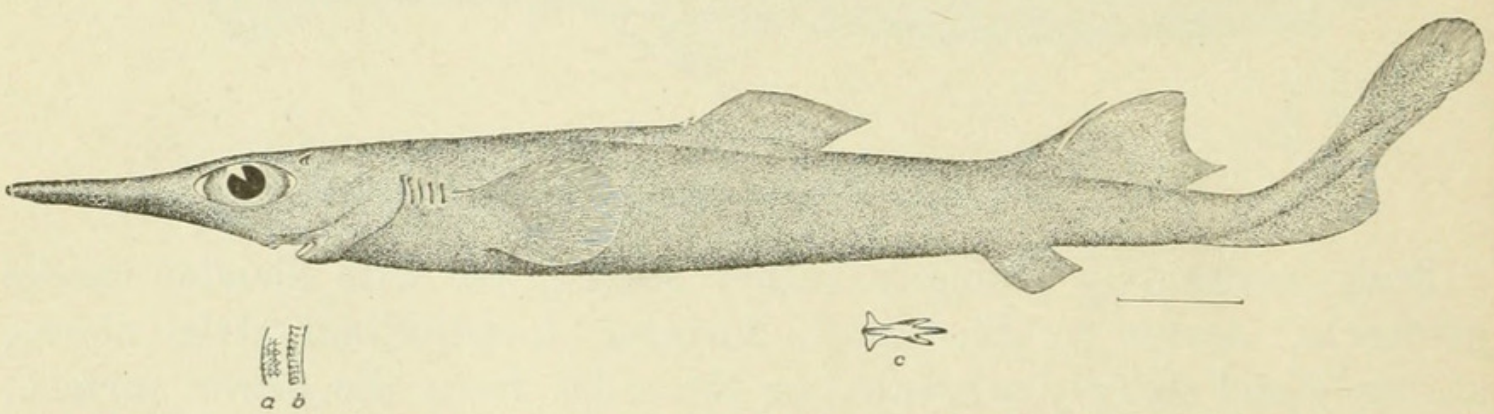

Fig. 2.-Deania Eglantina. $a$, upper jaw; $b$, lower jaw; $c$, scale (much enlarged).

Body rather elongate and slender; scales each with 3 or 4 short, radiating, bristle-like spines with two small prickles on each side, the whole body having a kind of hairy appearance, and velvety to the touch. The peculiar striated markings seen in Etmopterus are wanting.

Head large, greatly depressed; snout long, depressed, and broad; eyes large, lateral, and the anterior margin nearer the tip of the snout than the gill-opening; skin around the eyes more or less loose and free; nostrils large, on the lower side of the snout laterally and about midway between the tip of the snout and the eye; mouth opening 
below the posterior part of the eye, and rather broad; lips moderately fleshy; teeth small, compressed, and with small basal cusp; spiracle rather large, nearer the eye than the first gill-opening and the space between a little more than the length of the snout; gill-openings in front of the base of the pectoral, the longest about half the eye.

Dorsal fins each with a spine, the base of the first a little behind the tip of the pectoral, rather short, sharply pointed, and projecting little above the skin; second dorsal spine nearly as high as the fin, and the upper half exposed; pectorals about equal to the snout; ventrals small, posterior, and entirely in front of the second dorsal spine; caudal elongate, and the lower lobe little produced.

Color in spirits uniform dark grayish brown, almost black, the tips of spinules pale.

This description from a young female from Totomi Bay, off Numazu, 12 inches in length. It was dredged by the United States Fish Commission steamer Albatross in 1900 , and is numbered 49524 in the United States National Museum.

The genus Deania, named in honor of Dr. Bashford Dean, in recognition of his researches on Selachian fishes, is an ally of Centrophomus, from which it is distinguished by its velvety squamation, each scale ending in three or four radiating spinules arranged in the fashion of a star.

Proc. N. M. vol. $\mathrm{xxv}-02-6$ 


\section{$2 \mathrm{BHL}$ Biodiversity Heritage Library}

Jordan, David Starr and Snyder, John Otterbein. 1902. "Descriptions of two new species of squaloid sharks from Japan." Proceedings of the United States National Museum 25(1279), 79-81. https://doi.org/10.5479/si.00963801.25-1279.79.

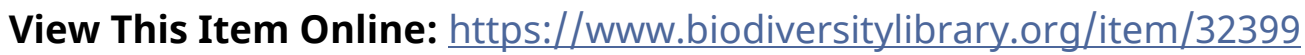
DOI: https://doi.org/10.5479/si.00963801.25-1279.79

Permalink: https://www.biodiversitylibrary.org/partpdf/9150

\section{Holding Institution}

Smithsonian Libraries

\section{Sponsored by}

Smithsonian

\section{Copyright \& Reuse}

Copyright Status: NOT_IN_COPYRIGHT

This document was created from content at the Biodiversity Heritage Library, the world's largest open access digital library for biodiversity literature and archives. Visit BHL at https://www.biodiversitylibrary.org. 